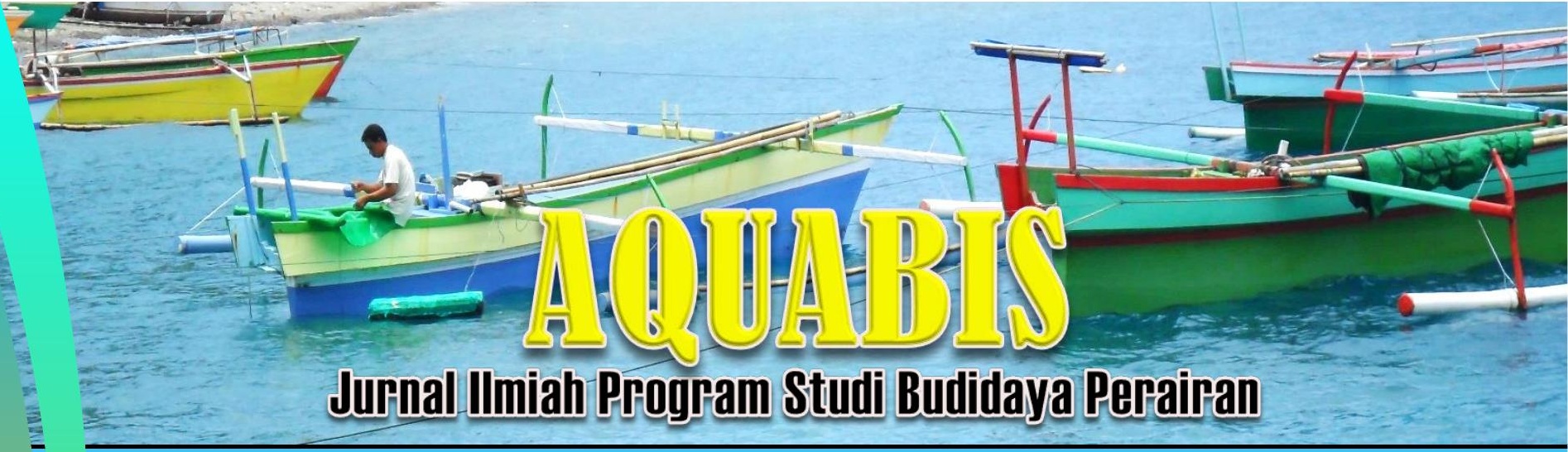

Volume 6 Nomor 1 Juni 2017

ISSN: 2301-5705

FAKTOR TEKNIS PENANGKAPAN TERHADAP DAMPAK TEKANAN POPULASI IKAN CAKALANG (Katsuwonus pelamis) DI PERAIRAN LAUT FLORES

Asruddin 1

KONSENTRASI LOGAM BERAT TIMBAL (PB) PADA SEDIMEN DAN IKAN NILA (Oreochromis niloticus) DI SUNGAI BIYONGA KABUPATEN GORONTALO

Sri Yuningsih Noor. 7

ANALISIS KELAYAKAN PANGKALAN PENDARATAN IKAN (PPI) TENDA KOTA GORONTALO DITINJAU DARI FASILITAS POKOK, FUNGSIONAL, DAN PENUNJANG

Muh. Yasin Umsini Putra Oli’ii dan Noval Saputra Yintili.... 13

BUDIDAYA IKAN AIR TAWAR SISTEM POLIKULTUR MENGGUNAKAN JARING TANCAP DI DANAU LIMBOTO

Yulianty Adipu

PEMANFAATAN KEONG MAS (Pomacea caniculata) SEBAGAI SUMBER BAHAN BAKU PAKAN IKAN

Titin Liana Febriyanti.

FREKUENSI PENCUCIAN YANG BERBEDA TERHADAP KEKUATAN GEL DAN PROTEIN LARUT GARAM SURIMI IKAN MANGGABAI (Glossogobius giuris)

Rahyuni Sy. Domili.

TELAAH KOMPOSISI IKAN KARANG DAN KOMUNITAS KARANG KELURAHAN BUNTA II DAN DESA MINAHAKI KABUPATEN BANGGAI Mohamad Sayuti Djau 


\title{
PEMANFAATAN KEONG MAS (Pomacea caniculata) SEBAGAI SUMBER BAHAN BAKU PAKAN IKAN
}

\author{
Titin Liana Febriyanti \\ Program Studi Budidaya Perairan Fakultas Ilmu-Ilmu Pertanian, \\ Universitas Muhammadiyah Gorontalo \\ Email: titinlianaf@yahoo.com
}

\begin{abstract}
Fish growth is influenced by several factors, one of which is feed. To overcome the high price of feed, the cultivators need to find alternative raw materials as a substitute for fish meal. One source of animal protein that can be a substitute for fish meal is mas snail flour (Pomacea caniculata). The purpose of this study is to know the benefits of snail pests as a source of raw materials of fish feed, knowing the best formulation for fish feed and to determine which protein content is best in fish feed. The experimental design used was Completely Randomized Design (RAL) consisting of 5 treatments with 3 replications. From the research results can be seen that the best formulation is the C treatment of 50\% fish meal and 50\% golden snail flour, with the highest protein content of $34.26 \%$.
\end{abstract}

Keywords: Feed, snail mas, formulation, and protein.

\begin{abstract}
Abstrak
Pertumbuhan ikan dipengaruhi oleh beberapa faktor, salah satunya adalah pakan. Untuk mengatasi tingginya harga pakan, maka pembudidaya perlu mencari bahan baku alternatif sebagai pengganti tepung ikan. Salah satu sumber protein hewani yang dapat menjadi pengganti tepung ikan adalah tepung keong mas (Pomacea caniculata). Tujuan dari penelitian ini adalah untuk mengetahui manfaat hama keong mas sebagai sumber bahan baku pakan ikan, mengetahui formulasi yang terbaik untuk pakan ikan dan untuk mengetahui kandungan protein mana yang terbaik pada pakan ikan. Rancangan percobaan yang digunakan ialah Rancangan Acak Lengkap (RAL) yang terdiri dari 5 perlakuan dengan 3 ulangan. Dari hasil penelitian dapat dilihat bahwa formulasi yang terabaik adalah perlakuan $\mathrm{C}$ yaitu $50 \%$ tepung ikan dan 50\% tepung keong mas, dengan kandungan proteinnya yang tertinggi yaitu $34,26 \%$.
\end{abstract}

Kata kunci: Pakan, keong mas, formulasi, dan protein.

\section{PENDAHULUAN}

Pertumbuhan ikan dipengaruhi oleh beberapa faktor, salah satunya adalah pakan. Untuk dapat tumbuh dengan baik ikan membutuhkan nutrisi yang lengkap. Pemberian pakan harus diperhatikan secara serius karena pakan berperan sebagai sumber nutrien utama untuk pertumbuhan ikan. Menurut (Craig, 2009) kualitas dan kuantitas nutrien yang baik merupakan dasar untuk menghasilkan ikan yang sehat dan berkualitas. Untuk itu, dalam pembuatan pakan diperlukan formulasi yang tepat sesuai dengan kebutuhan nutrien ikan nila. Selain kandungan protein, komposisi yang lain pun harus disesuaikan kebutuhan ikan.

Besarnya biaya operasional dalam pembuatan pakan disebabkan oleh tingginya harga pakan komersial yang menggunakan tepung ikan sebagai bahan baku utama. Untuk mengatasi tingginya harga pakan komersial karena mahalnya tepung ikan, maka pembudidaya perlu mencari bahan baku alternatif sebagai pengganti tepung ikan. Salah satu sumber protein hewani yang dapat menjadi pengganti tepung ikan adalah tepung keong mas (Pomacea caniculata). Keong mas merupakan hewan yang masuk dalam kelas Gastropoda, yang biasanya terdapat di sawah yang menggaggu tanaman padi . Karena keong mas memakan batang padi yang biasanya waktu mulai muncul biji padinya.

Adanya permasalahan diatas maka para pembudidaya perlu mancari pakan alternatif dari tepung ikan. Salah satu sumber protein hewani dalam pakan ikan yang dapat menjadi 
pengganti tepung keong mas. Pakan buatan dangan bahan baku keong mas ini harapannya mampu menekan biaya produksi karena harganya lebih murah dan hama pada tanaman padi berkurang, serta mampu memberikan pengaruh yang baik bagi pertumbuhan ikan. Tujuan dari penelitian ini adalah melihat peran tepung keong mas, formulasi mana dari penambahan tepung keong mas, dan protein tertinggi dari penambahan tepung keong mas.

\section{METODE PENELITIAN Alat dan Bahan}

Alat yang digunakan dalam penelitian ini adalah: tepung kedelai, tepung tapioka, tepung jagung, minyak ikan, minyak jagung, dan premix. Sedangkan alat yang digunakan adalah Penggiling, Blander, timbangan, loyang, baskom, spatula, dan alat tulis.

\section{Rancangan Percobaan}

Penelitian dilakukan dengan metode Rancangan Acak Lengkap (RAL) yang terdiri dari 5 perlakuan dengan 3 kali ulangan. Komposisi bahan baku yang akan dijadikan formulasi pakan dapat dilihat pada Tabel 1 . Masing-masing perlakuan terdiri dari; 1) Perlakuan A dengan komposisi $100 \%$ tepung ikan dan $0 \%$ tepung keong mas, 2) Perlakuan B yakni $75 \%$ tepung ikan dan $25 \%$ tepung keong mas, 3) Perlakuan $\mathrm{C}$ terdiri dari 50\% tepung ikan dan 50\% tepung keong mas, 4) Perlakuan D terdiri dari 25\% tepung ikan dan $75 \%$ tepung keong mas, 5) Perlakuan E terdiri dari $0 \%$ tepung ikan dan $100 \%$ tepung keong mas.

Tabel 1. Komposisi bahan baku pakan (gram)

\begin{tabular}{lrrrrr}
\hline \multirow{2}{*}{ Bahan Pakan } & \multicolumn{5}{c}{ Perlakuan } \\
\cline { 2 - 6 } & \multicolumn{1}{c}{ A } & \multicolumn{1}{c}{ C } & \multicolumn{1}{c}{ D } & \multicolumn{1}{c}{ E } \\
\hline Tepung ikan & 1126 & 844,5 & 563 & 281,5 & 0 \\
Tepung Keong mas & 0 & 281,5 & 563 & 844,5 & 1126 \\
Tepung kedelai & 563 & 563 & 563 & 563 & 563 \\
Tepung jagung & 511 & 511 & 511 & 511 & 511 \\
Tepung tapioka & 100 & 100 & 100 & 100 & 100 \\
Minyak ikan & 75 & 75 & 75 & 75 & 75 \\
Minyak jagung & 75 & 75 & 75 & 75 & 75 \\
Premix & 50 & 50 & 50 & 50 & 50 \\
\hline Total & 2500 & 2500 & 2500 & 2500 & 2500 \\
\hline
\end{tabular}

\section{Prosedur Penelitian}

Pembuatan Tepung Keong Mas (P. caniculata)

Keong mas dicuci dan direbus selama 30 menit, kemudian pengambilan daging, setalah itu daging dicuci kembali dan dipotong-potong untuk dijemur. Penjemuran dilakukan 2-3 hari di bawah panas matahari (dalam kondidi cuaca panas), setelah kering dilakukan penggilingan (tepung keong mas). Semua bahan yang sudah dipersiapkan dicampur sesuai komposisi yang telah ditentukan dan kemudian dilakukan pencetakan (pellet). Selanjutnya pakan yang sudah dicetaak dijemur sampai pellet kering $( \pm$ 12 jam), kemudian disimpan di tempat yang kering (toples).

Ikan yang sudah dikalimatisasi ditebar dalam wadah penelitian sebayak 20 ekor per $25 \mathrm{~cm}$ air. Sebelum ikan dimasukan, dilakukan sampling awal pertumbuhan ikan nila gift. Pemeliharaan benih ikan nila gift dilakukan selama 56 hari dengan pemberian pakan sebanyak 5\% dari bobot tubuhnya. Pemberian pakan dilakukan tiga kali sehari yaitu pukul 06.00 WIB, pukul 13.00 WIB dan pada pukul 18.00 WIB. Selama pemeliharaan dilakukan penyiponan setiap pagi hari dan pergantian air sebanyak $20 \%$ dari total volume air di akuarium untuk membersihkan sisa pakan dan feses.

Parameter Penelitian

Parameter yang akaan dilakukan dalam penelitian ini adalah uji proksimat dari setiap perlakuan. Adapun parameter uji proksimat yang dilakukan adalah:

1) Kadar Protein (AOAC, 1995)

Pengukuran kadar protein dilakukan dengan metode mikro-Kjeldahl. Kadar protein kasar dapat dihitung dengan rumus: 
KadarN $\%=\frac{(\text { mlsampel }- \text { mlHClblanko }) \times N H C l \times 14,007 \times 100 \%}{\text { Beratsampel }(\mathrm{mg})}$

Kadar Protein $(\%)=\% \mathrm{~N}$ x 6,25

2) Kadar Karbohidrat by difference (Winarno, 2004)

Pengukuran karbohidrat dilakukan dengan cara by difference, yaitu dihitung dengan menggunakan rumus :

$$
\begin{aligned}
\% \text { Karbohidrat }= & 100 \%-(\% \text { air }+\% \text { protein }+ \\
& \% \text { lemak }+\% \text { abu })
\end{aligned}
$$

3) Kadar Lemak (AOAC, 2007)

Kadar lemak dapat dihitung berdasarkan rumus:

$\%$ Kadar Lemak $=\frac{\text { berat lemak }(g)}{\text { berat } \operatorname{sampel}(g)} \times 100 \%$

Berat Lemak $=($ Berat Labu + Berat sampel)-Berat Labu

4) Kadar Air (AOAC, 2007)

Persentase kadar air (berat basah) dapat dihitung dengan rumus sebagai berikut:

$\%$ Kadar Air $=\frac{a-b}{c} \times 100 \%$

Keterangan :

$a=$ Berat Awal

$\mathrm{b}=$ Berat Akhir

$\mathrm{c}=$ Berat Sampel

5) Kadar Abu (AOAC, 1995) Kadar abu dapat dihitung dengan rumus:

$\%$ Kadar Abu $=\frac{\text { beratabu }(g)}{\text { beratsampel }(g)} \times 100 \%$

\section{Analisis Data}

Data yang diperoleh dari hasil uji proksimat disajikan dalam bentuk histogram, tabel/gambar kemudian diinterpretasikan dalam bentuk analisis diskriptif dan dibandingan setiap perlakuan.

\section{HASIL DAN PEMBAHASAN}

Hasil dari penelitian ini dilakukan uji proksimat di Laboratorium THP Politeknik Negeri Lampung. Hasi uji proksimat dapat dilihat pada Tabel 2. Penelitian dilakukannya analisis uji proksimat dilakukan di Laboratorium THP Lampung. Hasil analisis proksimat diperoleh nilai kandungan nutrisi dengan persentase yang berbeda-beda. Nilai kandungan nutrisi yang dihasilkan berbedabeda pada setiap perlakuan dikarenakan proporsi dari tepung keong mas dan tepung ikan dalam pakan memiliki persentase yang berbeda.

Formulasi pakan perlu dilakukan untuk menentukan nutrisi yang dibutuhkan dalam pakan. Penyusun utama komponen pakan buatan adalah protein. Protein merupakan senyawa kompleks yang terdiri dari asam-asam amino (NRC 1983). Watanabe (1988) menjelaskan bahwa pertumbuhan ikan sangat erat kaitannya dengan ketersedian protein dalam makanan, karena protein merupakan zat makanan yang sangat dibutuhkan ikan untuk pertumbuhan. Dengan adanya pemanfaatan protein makanan diharapkan protein tubuh pun akan bertambah sehingga terjadi pertumbuhan yang salah satu menjadi indikatornya ialah pertambahan bobot ikan.

Hasil penelitian dapat dilihat bahwa protein tertinggi terdapat pda perlakuan $\mathrm{C}$ yaitu $50 \%$ tepung ikan dan50\% tepung keong mas. Kemudian diikuti perlakuan D dan E yang masing-masing $(34,26 \%$ dan $34,24 \%)$, berikutnya perlakuan A $(29,5 \%)$ dan kadar protein terendar perlakuan B $(29,47)$. Dari hasil proksimat kadar protein untuk perlakuan $\mathrm{C}$ dapat diterapkan dalam pembuatan pakan, yaitu tepung ikan dengan tepung keong mas masing-masing $50 \%$ dapat memberikan kebutuhan ikan untuk pertumbuhan yang terbaik. Tetapi, untuk perlakuan D dan E, juga dapat diterapkan dalama pembuatan pakan,karena memiliki kandungan protein yang cukup tinggi untuk kebutuhan pertumbuhan ikan. 
Tabel 2. Data analisis proksimat tiap perlakuan

\begin{tabular}{lrrrrr}
\hline & \multicolumn{5}{c}{ T. Ikan dan T. keong Mas } \\
\cline { 2 - 6 } Parameter (\%) & $100 \%: 0 \%$ & $75 \%: 25 \%$ & $50 \%: 50 \%$ & $25 \%: 75 \%$ & $0 \%: 100 \%$ \\
\cline { 2 - 6 } & Perlakuan & Perlakuan & Perlakuan & Perlakuan & Perlakaun \\
& $\mathrm{A}$ & \multicolumn{1}{c}{$\mathrm{B}$} & \multicolumn{1}{c}{$\mathrm{C}$} & $\mathrm{D}$ & \multicolumn{1}{c}{$\mathrm{E}$} \\
\hline Air & 6,92 & 6,34 & 6,85 & 6,61 & 7,89 \\
Abu & 9,76 & 9,79 & 10,06 & 9,32 & 8,94 \\
Protein & 29,5 & 29,47 & 35,26 & 34,26 & 34,23 \\
Lemak & 9,1 & 11,23 & 10,86 & 11,64 & 12,22 \\
Serat Kasar & 1,24 & 0,67 & 1,55 & 1,9 & 1,96 \\
Karbohidrat & 43,45 & 42,48 & 35,39 & 35,61 & 34,73 \\
Energi (kkal) & 428,88 & 444,75 & 447,62 & 450,79 & 448,93 \\
\hline
\end{tabular}

Berikutnya lemak merupakan sumber utama penghasil energi selain protein (Afrianto dan Liviawaty, 2005). Kandungan lemak pakan mempunyai peran penting bagi ikan tropis karena selain sumber energi juga untuk memelihara bentuk dan fungsi membran atau jaringan dan steroid yang penting bagi organ tubuh tertentu serta untuk mempertahankan daya apung tubuh. Karbohidrat merupakan salah satu komponen sumber energi. Tingkat pemanfaatan karbohidrat oleh ikan umumnya rendah, khususnya pada ikan karnivora, karena pada ikan sumber energi utamanya adalah protein. Ikan karnivora lebih sedikit mengkonsumsi karbohidrat dibandingkan dengan omnivora dan herbivora.

Energi yang terdapat pada perlakuan D adalah yang paling besar yaitu 450,79 kkal. Sedangkan pada perlakuan C adalah $447,62 \%$ yang merupakan pertumbuhan terbaik, hal ini menunjukkan bahwa energi yang tinggi tidak menentukan pertumbuhan yang baik. Tetapi energi yang banyak digunkan menentukan pertumbuhan yang baik, sehingga perlakuan $\mathrm{C}$ paling baik pertumbuhannya. Berdasarkan analisis harga pakan terlihat bahwa semakin banyak proporsi tepung keong mas, maka biaya pakan yang di keluarkan semakin menurun, sehingga pada akhirnya akan menurunkan biaya produksi. Menurunnya biaya pakan disebabkan harga tepung keong mas yang relatif murah.

\section{KESIMPULAN}

Hasil penelitian didapatkan bahwa formulasi yang terabaik adalah perlakuan $\mathrm{C}$ yaitu 50\% tepung ikan dan 50\% tepung keong mas, dengan kandungan proteinnya yang tertinggi yaitu $34,26 \%$.

\section{DAFTAR PUSTAKA}

Afrianto, E dan Liviawaty, E. 2005. Pakan Ikan. Kanisius. Yogyakarta. $148 \mathrm{hlm}$.

AOAC. 1995. Official Methods of Analysis of The Association of Analytical Chemists, Washington D.C.

AOAC. 2007. Official Methods of Analysis of AOAC International. 18th Edition. Gaithersburg: AOAC International.

Craig, S., L.A.Helfrich. 2009. Understanding Fish Nutrition, Feed, and Feeding. Virgina Cooperation extension. Publication 420-256.

National Research Council (NRC). 1983. Nutrient Requirement of Warmwater Fishes. National Academy Press, Washington DC. $71 \mathrm{hlm}$.

Watanabe, T. 2001. Fish Nutrition and Marine Culture. Departement of Aquatic Bioscience. Tokyo University of Fisheries

Winarno, F.G. 2004. Kimia Pangan dan Gizi. Gamedia Pustaka Utama, Jakarta. 